UMIBARA

Indonesian Journal of Anthropology

Volume 5 (2) Desember 2020 || eISSN 2528-1569 | pISSN 2528-2115 || http://jurnal.unpad.ac.id/umbara

DOI : $10.24198 /$ umbara.v5i2.30656

\title{
Dari Salaman ke Senyuman: Dampak Kebijakan Kesehatan Global terhadap Komunitas Lokal di Era Pandemi
}

\author{
Elsa Lutmilarita Amanatin ${ }^{1}$, Naila Rahmaniyatul Wulida ${ }^{2}$, Handika Mukti ${ }^{3}$, Kuncoro Bayu \\ Prasetyo $^{4}$, Noviani Achmad Putri ${ }^{5}$, dan Didi Pramono 6 \\ ${ }^{1}$ Program Studi Sosiologi dan Antropologi, FIS, Universitas Negeri Semarang \\ elsalutmilarita@students.unnes.ac.id \\ ${ }^{2}$ Program Studi Sosiologi dan Antropologi, FIS, Universitas Negeri Semarang \\ naila2424@students.unnes.ac.id \\ ${ }^{3}$ Program Studi Sosiologi dan Antropologi, FIS, Universitas Negeri Semarang \\ handikamukti99@students.unnes.ac.id \\ ${ }^{4}$ Program Studi Sosiologi dan Antropologi, FIS, Universitas Negeri Semarang \\ mrbayu@mail.unnes.ac.id \\ ${ }^{5}$ Program Studi Pendidikan Ilmu Sosial, FIS, Universitas Negeri Semarang \\ noviani.ips@mail.unnes.ac.id \\ ${ }^{6}$ Program Studi Sosiologi dan Antropologi, FIS, Universitas Negeri Semarang \\ didipramono@mail.unnes.ac.id
}

\begin{abstract}
This study describes change of people's behavior in Debong Kidul, Tegal, in response to global policies due to Covid-19 pandemic. The Covid-19 pandemic that emerged since the beginning of 2020 has significant impact to human life around the world, including changing people's physical interaction. This research applied qualitative methods. Data of this study were collected through direct observation, online interviews, and literature study. The finding of this study suggests that the global health policy on physical distancing was responded by the Government of Tegal by issuing local regulations to prohibit the handshaking habit during the Covid-19 pandemic. This regulation has reduced people's habit of handshaking. However, people has adopted a new habit to substitute handsake during the social interaction by smiling.
\end{abstract}

Keywords: Covid-19, global health policy, local communities, pandemic, social transformation

\begin{abstract}
Abstrak
Penelitian ini membahas perubahan perilaku masyarakat di Debong Kidul, kota Tegal, sebagai respon terhadap kebijakan global terkait pandemi Covid-19. Pandemi Covid-19 yang terjadi sejak awal tahun 2020 telah berdampak signifikan terhadap kehidupan manusia di seluruh dunia, termasuk mengubah cara berinteraksi secara fisik yang berisiko menyebarkan virus Covid-19. Penelitian ini dilakukan dengan
\end{abstract}


menggunakan metode kualitatif. Sumber data diperoleh melalui observasi langsung, wawancara online, dan studi pustaka. Hasil penelitian menunjukkan bahwa kebijakan kesehatan global berupa physical distancing, direspon oleh Pemerintah Kota Tegal dengan mengeluarkan peraturan daerah yang melarang kebiasaan berjabat tangan dalam interaksi sosial selama pandemi Covid-19. Kebijakan tersebut membawa perubahan sosial di masyarakat sehingga kebiasaan berjabat tangan pun banyak berkurang. Masyarakat lokal di Debong Kidul secara adaptif menemukan pengganti jabat tangan saat berinteraksi yaitu dengan senyuman.

Kata kunci: Covid-19, kebijakan kesehatan global, komunitas lokal, pandemi, transformasi sosial

\section{Pendahuluan}

Pada awal 2020, dunia digemparkan dengan merebaknya Coronavirus jenis baru yaitu SARS-CoV-2 dan penyakitnya disebut Coronavirus Disease 2019 (COVID-19). Coronavirus merupakan virus RNA strain tunggal positif, berkapsul dan tidak bersegmen. Coronavirus tergolong ordo Nidovirales, keluarga Coronaviridae dengan struktur seperti kubus, memiliki protein $\mathrm{S}$ di permukaan virus. Protein $\mathrm{S}$ berperan dalam penempelan virus ke dalam sel host (interaksi protein $\mathrm{S}$ dengan reseptornya di sel inang) yaitu pada tubuh manusia (Wang, Qiang, Ke, 2020).

Saat ini, risiko kematian akibat infeksi virus corona diperkirakan 3-4\% lebih kecil dibandingkan SARS (11\%) dan MERS (35\%). Namun, virus ini cenderung lebih mudah menyebar karena ditularkan melalui kontak fisik, atau melalui droplet dari percikan air mulut atau hidung saat batuk dan bersin (Pesheva, 2020). Selain itu, penularan juga terjadi secara tidak langsung lewat permukaan benda yang terkontaminasi virus. Virus Covid-19 dapat bertahan di udara selama 30 menit, sehingga memungkinkan untuk menempel ke berbagai objek (Wang, Qiang, Ke, 2020).

Satuan tugas penanganan Covid-19 di Indonesia menyatakan jumlah kasus positif Covid-19 mencapai 121.226 per tanggal 7 Agustus 2020 (Liputan6.com, 2020). Jumlah ini melonjak tinggi sejak kasus positif Covid-19 pertama di Indonesia ditemukan pada awal bulan Maret 2020. Oleh karena itu, dalam rangka mengurangi tingkat penyebaran virus corona, pemerintah mem- berlakukan berbagai kebijakan baru, salah satunya yaitu social/physical distancing yang merupakan adaptasi dari kebijakan global yang dirumuskan oleh lembaga kesehatan dunia/ World Health Organization (WHO) yang berbunyi:
"Jadilah pahlawan dan putuskan mata rantai penularan Covid-19 dengan melatih jarak fisik. Artinya, kita men- jaga jarak minimal 1 meter dari satu sama lain dan menghindari meng- habiskan waktu di tempat keramaian atau berkelompok." (World Health Organization, 2020)

Covid-19 tidak hanya menimbulkan berbagai dampak di bidang kesehatan, pendidikan, ekonomi, teknologi, politik, dan hukum, tapi juga mempengaruhi interaksi sosial budaya di masyarakat. Salah satu perilaku budaya masyarakat Indonesia yang terdampak besar akibat kebijakan physical distancing tersebut adalah tradisi salaman atau jabat tangan yang merupakan salah satu cara masyarakat berinteraksi dalam menjalin hubungan sosial mereka. Berjabat tangan adalah tindakan yang menjadi simbol salam antar individu. Samantha dalam Cahyo (2017) mengungkapkan bahwa jabat tangan merupakan ritual pendek antara dua orang, berupa saling menggenggam tangan kanan atau kiri mereka, dan sering kali disertai oleh sentakan kecil pada tangan yang tergenggam. Berjabat tangan, merupakan perwujudan niat baik yang ditujukan kepada pihak yang tangannya dijabat. Secara implisit, 
jabat tangan mengirimkan isyarat keterbukaan. Kebiasaan jabat tangan menjadi salah satu bentuk komunikasi nonverbal.

Kebijakan physical distancing mencakup peraturan untuk menghindari kontak langsung dengan orang lain (Fong et al., 2020). Greenstone dan Nigam (2020) mengungkapkan bahwa penerapan physical distancing di beberapa negara dijalankan dengan cara yang beragam. Ada negara yang memberikan sanksi bagi pelanggar physical distancing, tapi ada pula negara yang hanya memberikan himbauan dan sosialisasi berkelanjutan tanpa disertai adanya sanksi.

Kebijakan kesehatan global yang diinisiasi oleh WHO tersebut juga direspon oleh pemerintah Indonesia. Pemerintah Indonesia memberikan instruksi bahwa pelaksanaan kebijakan social dan physical distancing harus melibatkan tokoh masyarakat hingga tingkat RT/RW (Sekretariat Kabinet Republik Indonesia, 2020). Kebijakan social dan physical distancing ditetapkan sejak awal untuk menyiasati tingginya risiko penularan melalui tangan saat berjabat tangan. Secara struktural birokratis, kebijakan penanganan pandemi Covid-19 termasuk physical distancing, diturunkan dari level provinsi, kabupaten/kota, hingga ke level desa. Di beberapa wilayah, kebijakan ini telah menghilangkan dan mengubah interaksi jabat tangan.

Di Kelurahan Debong Kidul Kota Tegal, tradisi berjabat tangan resmi ditiadakan sejak pandemi bermula sebagai bentuk penerapan kebijakan global physical distancing. Bahkan di masa new normal, kebijakan physical distancing masih diberlakukan. Walikota Tegal, Dedy Yon Supriyono menerbitkan Peraturan Walikota Nomor 13 Tahun 2020 tentang Pencegahan Penularan Covid-19 yang di dalamnya menyatakan dengan tegas agar masyarakat menaati protokol kesehatan wajib, yaitu memakai masker, menjaga jarak aman, dan melakukan physical distancing dan social distancing (Kompas.com, 2020). Peraturan ini merujuk pada protokol kesehatan yang dikeluarkan oleh WHO dan Gugus Tugas Penanggulangan Covid Nasional.

Peraturan lain, yaitu peraturan Walikota Tegal No. 13 Tahun 2020, pasal 8 ayat 3 secara eksplisit bahkan mengatur pembatasan kontak fisik dalam berinteraksi. Hal ini telah mendorong masyarakat untuk tidak lagi saling bersalaman sebagai perwujudan kepatuhan pada aturan physical distancing.

Hilangnya tradisi salaman sebagai salah satu interaksi sosial di masyarakat meskipun terlihat sepele, pada awalnya telah menimbulkan berbagai gejolak sosial. Sebab, tradisi salaman yang merupakan simbol dari kedekatan personal tiba-tiba harus dihilangkan. Salaman sebagai sebuah tindakan kontak primer ${ }^{1}$ merupakan simbolisasi dari kontak langsung, dan merupakan aspek paling umum dalam interaksi sosial.

Penelitian ini bertujuan menggambarkan dampak kebijakan global di masa pandemi, yaitu physical distancing di level mikro dengan mengedepankan pembahasan pada hilangnya tradisi salaman di Kampung Debong Kidul. Penelitian ini juga menggambarkan respon masyarakat di tingkat lokal terhadap kebijakan global tersebut.

\section{Kajian Pustaka}

\section{Covid-19 dan Perubahan Tradisi Komuni- kasi}

Tradisi berjabat tangan telah ada dalam budaya berbagai masyarakat, bahkan di Yunani Kuno (Oxlund, 2020). Berjabat tangan dilakukan untuk menunjukkan kepribadian dan rasa hormat kepada seseorang. Berjabat tangan bukan sekadar isyarat sapaan dan ucapan selamat berpisah, tetapi bervariasi dalam fungsi dan makna sesuai dengan konteks dan situasi sosial yang ada.

Tradisi salaman atau jabat tangan juga merupakan salah satu cara komunikasi tertua yang

\footnotetext{
${ }^{1}$ Kontak primer merupakan kontak yang terjadi saat individu satu dengan lainnya mengadakan hubungan langsung dengan bertemu dan bertatap muka (Soekanto, 2017).
} 
telah ada dalam berbagai tradisi kebudayaan dunia sejak berabad-abad silam (Cahyo, 2017). Tindakan berjabat tangan menjadi cara seseorang menyampaikan maksud menghormati orang lain. Budaya salam dengan berjabat tangan saat saling bertemu sudah melekat di dalam kehidupan masyarakat, termasuk di Indonesia. Namun, indahnya tradisi bersalaman kini terhalang oleh pandemi Covid-19. Kebijakan physical distancing secara tidak langsung berpengaruh terhadap hilangnya tradisi jabat tangan yang selama ini ada dalam kehidupan dan interaksi sosial masyarakat.

Tradisi bersalaman bagi masyarakat di Indonesia merupakan perilaku yang sangat penting dalam interaksi sosial karena di dalamnya terkandung berbagai makna sosial budaya. Hasil penelitian yang dilakukan di sebuah sekolah dasar di Riau menemukan fakta bahwa tradisi salaman dianggap sebagai simbol penting dari karakter anak. Oleh karena itu, tradisi ini disosialisasikan dan ditanamkan sejak dini pada anak-anak melalui program terstruktur di tingkat Sekolah Dasar di Pekanbaru Riau. Program Mushafahah (bersalaman) diciptakan sebagai upaya membangun karakter siswa dan dianggap sebagai salah satu solusi mengatasi penurunankarakter dan akhlak generasi muda saat ini (Pohan et al., 2017).

Munculnya pandemi Covid-19 ternyata memengaruhi eksistensi tradisi bersalaman. Pengaruh tersebut tidak hanya dirasakan oleh masyarakat Indonesia, melainkan juga dirasakan di berbagai belahan dunia. Caligiuri (2020) menyatakan bahwa terdapat tiga hal yang sangat sulit diubah dalam interaksi sosial manusia yaitu: salam, jarak sosial, dan sentuhan dalam percakapan. Namun, dalam kondisi pandemi, ketiga hal tersebut merupakan hal yang justru harus dihindari. Hal ini menjadi tantangan yang sangat besar dan tidak mudah bagi masyarakat. Namun, pada akhirnya, pandemi membuat masyarakat harus beradaptasi dengan perubahan, termasuk beradaptasi dalam perilaku dan cara berinteraksi sosial.

Pandemi Covid-19 menawarkan kesempatan untuk memajukan pemahaman manusia tentang pertolongan pertama dan perawatan kesehatan mental yang berfokus pada pencegahan, pada tingkat populasi, dan bahkan pada tingkat nasional, dan untuk keluar dari pandemi ini dengan cara yang baru (Galea et al., 2020). Hasil penelitian ini menjelaskan bahwa pandemi Covid-19 dapat berakibat pada adanya jaga jarak sebagai langkah preventif pencegahan pandemi. Selain itu pandemi juga berimplikasi pada upaya penjagaan kesehatan mental di tiap masyarakat. Salah satu fenomena yang muncul adalah sikap over-protective.

Penyebaran virus Covid-19 telah berdampak pada sikap masyarakat yang menjadi lebih over-protective terhadap kondisi lingkungan yang ditempati. Kekhawatiran terhadap Covid-19 memberikan pengaruh terhadap sikap sosial, khususnya terhadap proses interaksi sosial yang dilakukan setiap individu. Masyarakat menganggap bahwa menjauh dari kehidupan sosial secara normal lebih baik dilakukan pada saat ini. Akibatnya, muncul struktur sosial baru, kelompok sosial, aturan dan norma baru, perbedaan tingkatan atau stratifikasi sosial, pergeseran pola hidup, hingga kebiasaan-kebiasaan baru yang dijadikan sebagai kebudayaan dalam menjalani aktivitas sehari-hari. Pengelompokan dan pengkotakan terhadap masyarakat juga terjadi di masa ini (Harahap, 2020).

Penelitian di bidang komunikasi menemukan bahwa model komunikasi tidak langsung yang dilakukan selama pandemi Covid-19 dianggap sangat efektif sebagai teknik penyuluhan alternatif di masa pandemi, di mana kontak langsung dan pengumpulan massa dalam jumlah besar tidak diperkenankan (Harnika, 2020). Penyebaran Covid-19 melalui interaksi langsung telah membuat pemerintah di seluruh dunia berjuang mengimplementasikan kebijakan yang membatasi interaksi sosial. Hal ini untuk mengurangi beban rumah sakit, dan menyelamatkan nyawa lebih banyak orang; walaupun sifat drastis dari kebijakan physical distancing juga berpengaruh terhadap interaksi sosial masyarakat (Aquarini, 2020). 


\section{Covid-19 dan Perubahan Sosial}

Perubahan sosial yang terjadi di masa pandemi telah berimplikasi langsung pada kehidupan sosial kemasyarakatan yaitu adanya tatanan normal baru. Pemberlakuan tatanan normal baru mengubah pola interaksi sosial yang harus didasarkan kepada protokol kesehatan agar aman dari penyebaran Covid-19. Perubahan tersebut terjadi dalam interaksi individu dengan lingkungannya yang terdiri dari lingkungan keluarga inti, lingkungan kerabat, lingkungan tempat kerja, lingkungan tempat pemenuhan kebutuhan pokok, dan lingkungan tempat hiburan.

Di dalam konteks lingkungan keluarga, setiap anggota keluarga harus memahami dan mempraktikkan tatanan normal baru, yaitu dengan menerapkan perilaku hidup sehat dan bersih di dalam rumah. Di dalam konteks interaksi sosial di ruang publik, mulai dari interaksi dengan tetangga sampai kepada interaksi dengan rekan kerja diorientasikan kepada interaksi sosial yang menjaga jarak satu dengan yang lainnya, serta menggunakan alat pelindung diri seperti menggunakan masker mulut. Perubahan ini didasarkan kepada sikap kesigapan terhadap potensi penyebaran Covid-19.

Praktik pemberlakuan tatanan normal baru tersebut secara empiris dihadapkan pada beberapa tantangan yang terdiri atas tiga aspek, yaitu: pertama, menyangkut isi kebijakan tatanan normal baru; kedua, menyangkut para pihak yang ditunjuk untuk melaksanakan tatanan normal baru; dan ketiga, menyangkut masyarakat sebagai kelompok sasaran yang harus menaati dan mempraktikkan tatanan normal baru (Herdiana dan Nurul, 2020).

Pandemi Covid-19 tidak sekadar menimbulkan dampak sosial yang negatif. Hal ini sebagaimana temuan penelitian Erowati, et al. (2020) yang menyatakan bahwa adanya pandemi Covid-19 justru telah memunculkan potensi-potensi modal sosial dan solidaritas sosial pada masyarakat di Kabupaten Pati. Era pandemi telah mampu menghubungkan berbagai elemen sosial dalam masyarakat sehingga saling terhubung dan memberikan dukungan so- sial dalam berbagai bentuk, termasuk berbagai aktivitas berbasis modal sosial yang dilakukan oleh organisasi perempuan Persit Kartika Chandra Kirana Kabupaten Pati.

Berbagai peristiwa sosial yang terjadi seiring dengan merebaknya pandemi Covid-19 tersebut menunjukkan bahwa pandemi ini bukan hanya sekadar bencana kesehatan semata; akan tetapi juga telah mendorong perubahan sosial yang besar dalam kehidupan masyarakat secara global. Kemunculan pandemi Covid-19 dapat dilihat sebagai suatu fenomena perubahan sosial yang datang secara tidak terduga, atau dalam studi perubahan sosial dapat dikategorikan sebagai bentuk perubahan yang tidak direncanakan (unplanned changed) (Soekanto, 2017).

Konsep unplanned changed menjelaskan bahwa perubahan yang tidak direncanakan atau tidak dikehendaki berlangsung di luar jangkauan pengawasan masyarakat dan dapat menyebabkan munculnya dampak-dampak sosial yang tidak diharapkan oleh masyarakat. Sebagai oposisi dari konsep unplanned change, muncul konsep planned change atau perubahan yang dikehendaki atau direncanakan. Perubahan yang direncanakan didefinisikan sebagai sebuah perubahan yang telah dirancang atau direncanakan terlebih dahulu oleh pihak-pihak yang menghendaki terjadinya sebuah perubahan sosial. Salah satu ciri dari planned change adalah adanya aktor perubahan yang disebut sebagai agent of change yang mendorong dan mengarahkan perubahan sosial. Melalui agent of change, masyarakat direkayasa agar memiliki cara hidup baru, perilaku baru atau kehidupan baru yang dianggap lebih adaptif dengan situasi zaman. Pada skala entitas negara, para agent of change kebanyakan melakukan proses perubahan tersebut melalui proses yang struktural yaitu melalui politik kebijakan negara.

\section{Metode}

Penelitian ini dilakukan dengan menggunakan metode kualitatif dengan model grounded re- 
search. Model ini dipilih dengan tujuan menemukan teori berlandaskan data yang diperoleh di lapangan atau situasi sosial (Sugiyono, 2017). Penelitian ini dilakukan di Kelurahan Debong Kidul, Kota Tegal. Lokasi ini dipilih karena promosi perubahan salam dari jabat tangan menjadi senyuman sebagai dampak kebijakan global physical distancing. Subjek dalam penelitian ini adalah masyarakat Kelurahan Debong Kidul, Kota Tegal.

Penelitian ini dilakukan pada bulan Mei 2020. Pengumpulan data pada penelitian ini menggunakan sumber data primer dan sekunder ${ }^{2,3}$. Pengumpulan data primer dilakukan dengan wawancara terstruktur bersama ketua RT dan warga setempat serta observasi langsung di Kelurahan Debong Kidul RT 04 RW 03. Selain itu, observasi langsung juga dilakukan kepada objek yang diteliti. Data sekunder pada penelitian ini diperoleh dari dokumen-dokumen, laporan dan surat edaran dari pemerintah kota Tegal, dan berbagai literatur dari penelitian yang telah dilakukan. Analisis dan interpretasi data dilakukan secara deskriptif dengan mempertemukan data lapangan dengan konsep atau teori yang digunakan dan disajikan dalam bentuk deskripsi analitik.

\section{Hasil dan Pembahasan}

\section{Implementasi Kebijakan Penanganan Covid-19 di Kelurahan Debong Kidul}

Pemerintah Kota Tegal mengeluarkan Peraturan Walikota Nomor 13 Tahun 2020 tentang penanganan penularan Covid-19 yang memuat himbauan kepada masyarakat untuk menerapkan protokol kesehatan dengan memakai masker, menjaga jarak aman, dan melakukan physical distancing serta social distancing. Aparat Kelurahan Debong Kidul mensosialisasikan aturan tersebut secara perlahan-lahan dan bertahap kepada masyarakat sebagai bentuk respon pemerintah lokal pada aturan walikota. Salah satu anjuran pemerintah Kelurahan Debong Kidul kepada masyarakatnya adalah tidak melakukan kebiasaan bersalaman sementara selama penerapan physical distancing.

"Ini susah, mengingat kebiasaannya kita kan berjabat tangan di mana pun dengan orang lain sebagai wujud unggah-ungguh juga sama ngajeni ke orang lain tapi masanya lagi begini jadi diganti pake senyum yang super manis biar gak usah salaman.” (Wawancara dengan Bapak Surip, ketua RT 04 Debong Kidul, 15 Mei 2020)

Sosialisasi pemerintah terbantu dengan sosialisasi dari media masa lainnya yang menggencarkan penerapan physical distancing, seperti televisi dan berita-berita online. Selain itu, local lockdown pada bulan Juli yang sempat dilakukan di kota Tegal secara tidak langsung mentransfer pengetahuan masyarakat mengenai betapa bahayanya Covid-19. Penerapan isolasi yang ketat, penyebaran pamflet dan brosur dari rumah ke rumah (door to door) juga membantu proses implementasi kebijakan penanganan Covid-19 di Kota Tegal. Tidak hanya itu, pemerintah Debong Kidul juga mengadakan sosialisasi keliling setiap hari jam sembilan pagi, dan bekerja sama dengan para penceramah atau sesepuh masjid dan mushola agar mengingatkan masyarakat untuk menerapkan physical distancing di setiap pidato mereka.

\section{Dampak Kebijakan Physical Distancing da- lam Kehidupan Sosial Masyarakat Debong Kidul}

Masyarakat di Kelurahan Debong Kidul menjadi satu di antara masyarakat lainnya yang juga mendapatkan efek dari kebijakan global physical distancing selama masa pandemi. Kebijakan ini secara tidak langsung telah mengubah dan memengaruhi tradisi yang sudah menjelma dalam kehidupan masyarakat khususnya saat berinteraksi sosial. Hal ini karena interaksi

\footnotetext{
${ }^{2}$ Data Primer merupakan sumber data pertama yang langsung diperoleh dari lokasi penelitian atau objek penelitian (Bungin, 2007).

${ }^{3}$ Sumber data sekunder adalah sumber yang tidak langsung memberikan data pada pengumpulan data (Rahmawati, dan Emma, 2019).
} 
sosial sangat erat kaitannya dengan kontak fisik, sehingga ketika kebijakan physical distancing diterapkan, kebiasaan-kebiasaan masyarakat ketika berinteraksi juga turut terpengaruh.

Masyarakat menggunakan salaman sebagai simbol keterbukaan mereka. Salaman dilakukan setiap kali mereka memulai dan mengakhiri interaksi sosial. Mereka selalu melakukan tradisi salaman setiap kali bertemu dengan orang lain; sehingga ketika mereka tidak melakukan salaman, hal itu dianggap sebagai hal yang tabu dan mencerminkan ketidaksopanan.

Larangan salaman sebenarnya tidak tertulis secara eksplisit. Namun, larangan ini tetap dilaksanakan untuk mencegah penularan Covid-19 akibat kontak fisik. Larangan untuk bersalaman sebagai bagian kebijakan physical distancing yang dianjurkan oleh pemerintah lokal menyebabkan kecanggungan di masyarakat ketika mereka berinteraksi.

"Begini sebenarnya tidak ada himbauan langsungnya secara eksplisit tidak ada peraturan khususnya yang tertulis menyatakan dilarang salaman. Hanya saja kami dan masyarakat menyadari bahwa kewajiban berjaga jarak dan menghindari kontak fisik termasuk dalam menghapus kebiasaan salaman ketika bertemu satu sama lain. Itu perlu saat ini daripada malah terkena Covid-19." (Wawancara dengan Bapak Surip, Ketua RT 04 Debong Kidul, 15 Agustus 2020)

Pada awalnya, masyarakat masih melakukan salam seperti biasa ketika cara menebar senyuman belum disepakati. Namun, pemerintah yang paling dekat dengan masyarakat seperti ketua RT dan RW selalu mengadakan sosialisasi untuk menggerakkan himbauan physical distancing. Setelah sekian proses sosialisasi tersebut dilakukan, masyarakat beberapa kali tetap mengacuhkan himbauan tersebut dengan tetap berkerumun dan melakukan salaman. Pemerintah setempat ak- hirnya mencontohkan physical distancing bersama anggota keluarga dan tetangga-tetangga terdekatnya. Mereka melakukan salam dan sapaan dengan menebar senyum, sehingga akhirnya masyarakat lainnya sedikit demi sedikit mulai menerima cara baru tersebut. Hal ini terlihat dari kebiasaan baru menebar senyum yang sering dilakukan di setiap aktivitas masyarakat ketika bertemu tetangganya di depan rumah, tempat ibadah, maupun di tempat hajatan sebagai wujud kesopanan dan saling menghormati. Senyuman tersebut dilakukan melalui dua cara, yang pertama dengan menurunkan sejenak masker saat bertemu untuk sekadar menunjukkan senyum, dan yang kedua dengan cara tersenyum tanpa membuka masker, namun gestur senyum dapat tertangkap dari raut muka mereka. Tidak jarang senyuman tersebut juga dipadukan dengan anggukan kepala untuk memberikan penegasan penyampaian salam dengan senyuman tersebut.

Kesadaran dan kepatuhan masyarakat terhadap penerapan physical distancing muncul karena pada dasarnya masyarakat Debong Kidul memiliki karakteristik sikap grapyak dan semanak $^{4}$. Selain itu, maraknya pemberitaan di televisi mengenai kondisi yang semakin parah terkait penyebaran Covid-19, dan adanya kebijakan local lockdown yang sempat diterapkan di Kota Tegal secara tidak langsung semakin memberikan kontribusi terhadap pemahaman masyarakat mengenai Covid-19.

\section{Aktivitas di Masjid}

Penduduk Kelurahan Debong Kidul mayoritas beragama Islam. Aktivitas kegamaan dan kegiatan di masjid kampung terlihat menonjol dalam kehidupan sehari-hari. Namun, sejak fenomena Covid-19, kegiatan di masjid sempat lumpuh. Semua masjid dan mushola ditutup sementara. Tempat ibadah baru kembali dibuka dengan penerapan protokol kesehatan, salah satunya yaitu himbauan untuk tidak bersalaman saat berjumpa dengan jamaah lainnya. Kebiasaan salaman seringkali dilakukan saat usai melak-

\footnotetext{
${ }^{4}$ Grapyak dalam bahasa Jawa berarti ramah dan mudah bergaul, sedangkan semanak berarti memiliki sifat akrab atau rasa kekeluargaan yang tinggi.
} 
sanakan sholat. Namun, karena himbauan ini, masyarakat Kelurahan Debong Kidul tidak lagi melakukan salaman. Usai melaksanakan sholat, masyarakat langsung membereskan alat sholat mereka untuk segera pulang. Namun, saat mereka berjumpa satu sama lain, mereka tetap menyapa dengan memberikan senyuman dan anggukan.

Senyuman yang dilakukan oleh masyarakat Debong Kidul dapat menyampaikan salam satu sama lain. Mereka tidak perlu mengatakan maaf saat tidak melakukan salaman. Senyuman yang disertai dengan anggukan kepala sudah dapat mereka pahami sebagai pengganti kebiasaan salaman. Hal ini menunjukkan bahwa walaupun kebijakan physical distancing telah sampai pada tataran masyarakat lokal, tidak menyurutkan semangat budaya mereka untuk saling menyapa dalam rangka menjaga hubungan interaksi sosial.

"Kagok Mba, biasanya habis salat jamaah pasti saling bersalaman mangkanya kadang hampir lupa tetep mau salaman, tapi khotib selalu menyampaikan tiap kali selesai berjamaah untuk tidak usah salaman dulu. Dan sebenarnya ini tidak masalah, mengingat kondisinya sedang ada pandemi seperti ini, dan selama masjid masih boleh dihidupkan, protokol pun insyaAllah akan kami laksanakan." (Wawancara dengan Bapak Oto, Jamaah Masjid Baitus Syukur, 15 Mei 2020)

\section{Aktivitas Saat Berjumpa di Jalan}

Masyarakat Kelurahan Debong Kidul merupakan masyarakat yang ramah. Saat berjumpa di jalan pun mereka menyempatkan untuk saling salaman. Usai bersalaman dan saling menyapa, mereka biasanya membuat obrolan-obrolan kecil sebelum kemudian berjalan lagi melanjutkan perjalanannya. Kebiasaan tersebut mulai berubah seiring berjalannya waktu. Seiring munculnya pemahaman masyarakat terhadap bahaya Covid-19, mereka juga mulai menerapkan himbauan physical distancing. Himbauan ini salah satunya tidak melakukan salaman dan mengganti sapaan lainnya dengan menebar senyum.

"Tiap nonton TV liat berita isinya Covid-19 naik terus kasusnya, berita di hp juga, belum lagi tiap pagi jam 9 selalu ada mobil keliling buat himbauan patuhin jaga jarak sama hindari kontak fisik, jadi sekarang kalo ada yang mau salaman ya mau gak mau ditolak terus buru-buru lempar senyum biar tetep keliatan ramah, ngehindarin salaman kan biar saling jaga, himbauan dari masjid juga kan lagi ga boleh jabat tangan dulu di mana-mana." (Wawancara dengan Mbak Yuli, warga Kelurahan Debong Kidul, 15 Mei 2020)

Pada akhirnya, masyarakat mulai terbiasa dengan adaptasi kebiasaan baru sebagai pola hidup baru menghadapi pandemi Covid-19. Mereka tidak lagi melakukan kebiasaan salaman ketika berjumpa di jalan. Masyarakat menggunakan senyuman (baik dengan menurunkan masker atau disertai anggukan) sebagai media dalam berkomunikasi untuk mengirimkan pesan saling menghormati dan hidup dalam harmoni sosial. Kebiasaan baru ini pada awalnya hanya diterapkan oleh sebagian masyarakat. Namun, proses sosialisasi kepada masyarakat yang gencar dilakukan mendorong masyarakat untuk memahami menerapkan kebiasaan menebar senyum sebagai cara baru untuk saling menyapa.

\section{Aktivitas dalam Acara Hajatan}

Hajatan di masyarakat Debong Kidul merupakan salah satu tradisi yang sering dilakukan ketika mereka memiliki kepentingan seperti kelahiran bayi, sunatan, pernikahan maupun kematian. Acara hajatan menjadi salah satu aktivitas masyarakat yang berpotensi mengumpulkan banyak orang dalam satu tempat. Ketika banyak orang yang berkumpul, maka banyak pula peluang masyarakat itu untuk saling bersalaman. Di tengah pandemi Covid-19, masih banyak warga yang mengadakan acara man- 
$t u^{5}$ atau hajatan. Pemerintah lokal seperti RT atau RW menghimbau masyarakat untuk tetap melakukan physical distancing di acara man$t u$ tersebut dengan tujuan mencegah penularan Covid-19 tanpa melarang warga melakukan tradisi mantu dan hajatan lainnya. Masyarakat yang mengadakan acara harus memastikan adanya peralatan protokol kesehatan seperti alat cuci tangan, masker, dan sebagainya. Selain itu, warga harus sadar untuk tidak salaman terlebih dahulu. Mereka menuliskan himbauan dan permohonan maaf untuk tidak salaman langsung di tempat acara mantu dan hajatan. Salaman yang sering dilakukan antara tamu dan tuan rumah akhirnya diganti dengan menebar senyum.

Penerapan protokol kesehatan tersebut juga terlihat pada salah satu keluarga yang sedang melakukan hajat mantu ketika penelitian dilakukan. Di depan rumah terdapat peralatan cuci tangan dan dua orang petugas keamanan kampung yang menjaga dan mengawasi berjalannya hajatan agar tidak terlalu ramai dan tetap kondusif. Selain itu, tamu pun dibatasi untuk mencegah kerumunan.

\section{Respon Masyarakat terhadap Kebijakan Himbauan Tidak Bersalaman}

Di masa pandemi Covid-19 saat ini, masyarakat di Kelurahan Debong Kidul dihimbau untuk mengikuti protokol kesehatan guna memutus mata rantai penyebaran Covid-19. Hal ini sebagaimana diinstruksikan oleh Pemerintah Kota Tegal melalui Peraturan Walikota Nomor 13 Tahun 2020. Salah satu protokol kesehatan yang dianjurkan oleh WHO yaitu physical distancing yang di dalamnya mencakup peraturan untuk menghindari kontak langsung dengan orang lain (Fong et al., 2020).

Kebijakan global terkait physical distancing tersebut direspon secara adaptif dan kreatif oleh masyarakat Debong Kidul dengan memunculkan tradisi pengganti salaman atau berjabat tangan yaitu dengan senyuman selama masa pandemi Covid-19. Hal ini dilakukan guna menghindari kontak langsung sesuai dengan anjuran protokol kesehatan. Secara lebih spesifik, respon masyarakat terhadap kebijakan dan himbauan tidak bersalaman dapat dilihat pada aspek perilaku sosial yang mengalami pergeseran. Perubahan budaya dari berjabat tangan ke senyuman yang terjadi di masyarakat Kelurahan Debong Kidul mendapatkan berbagai respon dari masyarakat. Berdasarkan hasil wawancara melalui telepon WhatsApp dengan ketua RT 04, Bapak Surip (48 tahun) menyatakan bahwa perilaku warga pada awal diterapkannya kebiasaan ini cenderung masih susah memahami perubahan kebijakan yang ditandai dengan belum adanya perubahan perilaku signifikan dengan mengganti kebiasaan bersalaman dengan senyuman. Hanya sebagian orang saja yang mulai tersadar untuk mengubah gaya berjabat tangannya dengan senyuman dan disertai dengan anggukan kepala atau menyatukan tangan di depan dada guna menghindari berjabat tangan seperti biasanya.
"Awal-awal ya masih ada yang susah, maune tetep salaman aja tapi makin ke sini yang tetep mau salaman itu nemuin orang yang pas diajak salaman udah ga mau akhirnya dia ikut tidak salaman lagi. Mereka mengganti dengan senyuman, carane seperti ini maskere dibuka sithik terus dikasih senyum biar tetep dapat ke- san menghormati."(Wawancara dengan Bapak Surip, ketua RT 04, 15 Mei 2020)

Kebiasaan berjabat tangan yang sudah menjadi kebudayaan di masyarakat Kelurahan Debong Kidul telah memberikan kesan tersendiri bagi mereka terkait perilaku menghormati dan menghargai. Namun, seiring gencarnya pemberian edukasi dan sosialisasi oleh pemerintah setempat dan melalui media elektronik, dan diterapkannya local lockdown oleh pemerintah kota ternyata mulai mampu memberikan perubahan perilaku warga masyarakat secara drastis. Mereka mulai mematuhi saran dari WHO untuk menghindari kontak fisik. Masyarakat mulai dapat

\footnotetext{
${ }^{5}$ Mantu dalam pengertian masyarakat Debong Kidul adalah sebuah ritual perayaan rasa syukur dan memohon keselamatan saat salah satu anggota keluarganya melangsungkan pernikahan, atau sunatan.
} 
memahami bahwa tindakan berjabat tangan cukup membahayakan di masa pandemi. Para tokoh setempat dan orang tua mulai menyadari hal ini dan menolak untuk melakukan berjabat tangan serta menggantinya dengan memberikan senyuman. Tindakan ini pun mulai diikuti oleh berbagai kalangan di masyarakat untuk mengubah berjabat tangan dengan senyuman bahkan ketika mereka bertemu di luar ruangan dengan kondisi menggunakan masker. Masyarakat setempat menyempatkan untuk menurunkan sedikit maskernya dan menunjukkan senyumannya. Jika tidak membuka masker, mereka menegaskan senyuman tersebut dengan anggukan kepala sebagai wujud menghormati dan simbol terjalinnya relasi personal yang hangat di antara anggota masyarakat (lihat gambar 1).

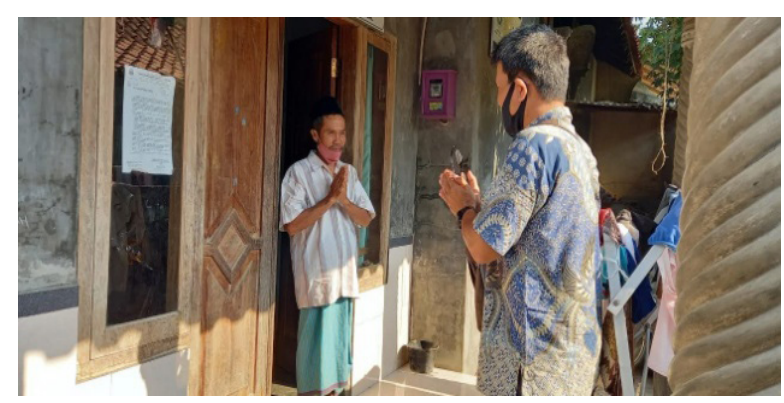

Gambar 1. Salah satu keluarga di Debong Kidul saat menerima tamu tidak lagi bersalaman (Sumber: Dokumentasi Peneliti)

\section{Dari Salaman Ke Senyuman: Proses Peru- bahan Perilaku Sosial Budaya Masyarakat Debong}

Skinner dalam Wardiah (2016) menyatakan bahwa perilaku adalah respon atau reaksi seseorang terhadap stimulus yang diberikan dari luar dirinya. Oleh karena itu, perilaku tidak dapat diduga karena sifatnya yang dapat berubah, diubah, dan berkembang sebagai wujud hasil interaksi individu yang bersangkutan dengan lingkungannya. Triwibowo (2015) menyatakan bahwa perilaku merupakan seperangkat perbuatan seseorang sebagai bentuk respon terhadap sesuatu dan kemudian diimplementasikan menjadi kebiasaan karena adanya nilai yang sedang diyakini. Apabila perilaku masyarakat kemudian dihubungkan dengan kebijakan pemerintah, maka perilaku tersebut mengindikasikan suatu reaksi ma- syarakat terhadap kebijakan pemerintah yang sedang dijalankan yang tercermin dalam bentuk tindakan langsung atau tindakan tidak langsung yang diyakininya.

Perilaku masyarakat Debong Kidul dalam merespon himbauan tidak bersalaman sebagai tafsir atas kebijakan physical distancing dipengaruhi oleh persepsi masyarakat terhadap ancaman bahaya Covid-19 sebagaimana informasi yang mereka terima dari media maupun dari pemerintah. Masyarakat memiliki persepsi dan meyakini bahwa apa yang disampaikan oleh pemerintah Kota Tegal tentang pandemi adalah kenyataan yang harus diterima dan dihadapi. Hal tersebut akhirnya membuat masyarakat pada akhirnya bersedia melakukan perubahan tradisi salaman dan menggantikannya dengan senyuman.

Pembentukan persepsi dipengaruhi oleh dua faktor yaitu faktor internal, yakni yang terdapat di dalam diri individu itu sendiri; dan faktor eksternal yang merupakan karakteristik dari lingkungan dan objek-objek di dalamnya (Gibson et al. dalam Notoadmodjo, 2010). Elemen-elemen tersebut mampu mengubah sudut pandang seseorang terhadap dunia sekitarnya dan mempengaruhi cara seseorang menerima dan merasakannya. Persepsi menjadi penting dalam proses perubahan, karena perilaku yang berubah dipengaruhi oleh persepsi yang terbentuk terhadap fenomena pandemi maupun terhadap peraturan walikota itu sendiri.

Pada awal sosialisasi himbauan dan kebijakan physical distancing, masyarakat masih tidak percaya dan tidak mematuhi himbauan tersebut. Berbagai pelanggaran seperti mengadakan kerumunan dan saling berjabat tangan masih dilakukan. Pada akhirnya, pemerintah lokal setempat seperti ketua RT, RW, dan kepala desa melakukan inisiasi untuk mengajak seluruh anggota keluarganya mematuhi kebijakan physical distancing. Mereka dihimbau untuk tidak perlu berjabat tangan saat bertemu dengan masyarakat lainnya, tetangga, dan orang lain, serta menggantikan jabatan tangan dengan senyuman. Waktu yang terus berjalan 
diiringi dengan banyaknya kasus positif virus Covid-19 termasuk di Kota Tegal membuat masyarakat semakin mengerti akan bahaya virus tersebut. Selain itu, masyarakat di Debong Kidul juga mulai memahami dan mengikuti cara anggota keluarga ketua RT, RW, dan perangkat desa lainnya yang selalu menebar senyum saat bertemu tanpa berjabat tangan. Hal ini menunjukkan bahwa keteladanan dari perilaku anggota keluarga perangkat desa sangat kuat mempengaruhi persepsi masyarakat dan menjalar sampai pada praktiknya secara nyata untuk tidak berjabat tangan selama pandemi.

Selain itu, sosialisasi yang gencar dilakukan oleh pemerintah lokal berhasil memberikan pemahaman kepada seluruh masyarakat mengenai bahaya Covid-19 dan keharusan melaksanakan physical distancing. Sosialisasi tersebut juga dibantu oleh pemerintah pusat melalui siaran televisi, kebijakan local lockdown dari pemerintah setempat, dan sebagainya. Serangkaian peristiwa yang menyertai fenomena Covid-19 memberikan pemahaman kepada masyarakat terhadap pentingnya tidak bersalaman di masa pandemi.

"Kan sekarang semua rumah udah punya TV, jadi mereka udah paham bahayanya Covid ini. Sama adanya local lockdown Juni kemarin juga bikin masyarakat makin paham kalo Covid ini bener-bener bahaya mangkannya sampe ada isolasi, edukasinya lewat brosur-brosur yang disebar di rumah-rumah, menyiapkan panduan cuci tangan, himbauan menghindari kerumunan dulu, sama mobil keliling yang selalu lewat tiap jam 9 pagi buat selalu ngingetin panduan protokol kesehatan." (Wawancara dengan Bapak Surip, ketua RT 04, 15 Agustus 2020)

Di dalam konteks studi perubahan sosial, apa yang terjadi pada masyarakat Debong Kidul di era pandemi dapat dianalisis sebagai sebuah proses perubahan sosial yang memiliki dua aspek sekaligus, yaitu aspek perubahan sosial yang tidak direncanakan atau unplanned change, namun di sisi lain juga merupakan perubahan yang direncanakan atau planned change (Soekanto, 2017). Pada aspek perubahan tidak direncanakan atau unplanned change, perubahan yang terjadi di Debong Kidul adalah suatu perubahan yang tidak pernah diduga terjadi pada kehidupan masyarakat setempat. Pandemi Covid-19 dalam hitungan bulan telah mengubah secara fundamental cara berinteraksi masyarakat Debong Kidul tanpa mereka pernah bersiap untuk menghadapinya. Ibarat petir di siang bolong, gelombang wabah Covid-19 secara tiba-tiba menyerang berbagai sendi sosial masyarakat, mengganggu kehangatan dan keintiman hubungan sosial yang selama ini terjalin di antara anggota komunitas, serta menimbulkan kepanikan dan kecemasan pada banyak anggota masyarakat.

Pada tahap berikutnya, respon terhadap perubahan yang tidak terencana tersebut diambil alih oleh pemerintah melalui penerbitan Peraturan Walikota Tegal No 13 Tahun 2020 tentang Pencegahan Penularan Covid-19. Peraturan walikota tersebut merujuk kebijakan pemerintah pusat Indonesia yang mengacu dari protokol penanganan Covid-19 yang diberlakukan secara global oleh badan kesehatan dunia WHO. Mengacu pada peraturan walikota tersebut, pemerintah kelurahan Debong Kidul beserta para tokoh masyarakatnya menerapkan kebijakan untuk menghilangkan tradisi bersalaman dalam pertemuan-pertemuan sosial dan menggantikannya dengan senyuman. Kebijakan struktural tersebut secara efektif telah berhasil mengubah perilaku masyarakat Debong Kidul yang meninggalkan tradisi salaman dan menggantikannya dengan senyuman. Alternatif pengganti salaman tersebut muncul dengan didukung karakter masyarakatnya yang grapyak dan semanak atau dikenal juga dengan ramah tamah.

Perubahan kebiasaan dari salaman ke senyuman di Kelurahan Debong Kidul dapat dilihat sebagai sebuah hasil dari proses perubahan yang direncanakan atau planned change. Hal yang menarik, planned change berupa kebijakan physical distancing ini merupakan policy response atau 
respon dari pengambil kebijakan yang muncul akibat sebuah proses unplanned change yaitu datangnya wabah pandemi yang tidak diduga-duga. Mengubah salaman ke senyuman bukanlah proses alami, melainkan proses yang dibangun dengan sengaja sebagai implementasi kebijakan global physical distancing. Unsur pokok konsep unplanned change yang dijelaskan Soekanto (2017) dapat terlihat dalam fenomena ini yaitu adanya pihak yang menginisiasi perubahan, dituangkan dalam bentuk kebijakan terencana berupa peraturan walikota, serta ditemukannya unsur agent of change dalam menginisiasi perubahan ini. Kebijakan walikota tersebut diimplementasikan oleh aparat kelurahan tokoh masyarakat di Kelurahan Debong Kidul sebagai kepanjangan tangan dari sistem birokrasi.

Aparat pemerintah lokal di Debong Kidul yang didukung oleh para tokoh masyarakat menjadi aktor penting yang memerankan diri sebagai agent of change dalam perubahan terencana tersebut. Kebijakan kesehatan global physical distancing yang diinisiasi oleh WHO ke seluruh dunia, pada akhirnya berhasil masuk hingga tataran mikro lokal hingga pelosok kampung Debong Kidul melalui jaringan struktur birokrasi pemerintahan yang ada di Indonesia. Pada akhirnya, keberhasilan negara melakukan intervensi kebijakan dalam melakukan perubahan perilaku tradisi masyarakat lokal untuk kepentingan perang global melawan pandemi Covid-19 khususnya di Tegal menjadi cerminan bahwa relasi global dan lokal tidak dapat diabaikan dan akan selalu membawa berbagai dampak baik positif dan negatif. Fenomena yang terjadi di Debong Kidul ini dapat menjadi cerminan bagaimana penanganan Covid-19 di Kota Tegal yang banyak dipuji pemerintah pusat dan berbagai survei nasional karena menjadi salah satu kota yang dianggap berhasil dalam penanganan Covid 19 dan menjadi satu-satunya kota di Pulau Jawa yang diperbolehkan oleh pemerintah pusat untuk melakukan aktivitas fisik dalam pendidikan, agama, sosial-budaya, dan ekonomi pada bulan Mei 2020 (CNN Indonesia, 2020).

\section{Simpulan}

Hasil penelitian menunjukkan bahwa kebijakan kesehatan global WHO dalam perang menghadapi pandemi Covid-19 berupa physical distancing telah berhasil mengintervensi model interkasi sosial di masyarakat lokal di Debong Kidul, Kota Tegal secara terencana melalui media struktur politik berupa peraturan Walikota Tegal. Kebijakan tersebut mengatur setiap masyarakat untuk menjaga jarak dan menghindari sentuhan fisik dengan orang lain untuk mengimplementasikan pencegahan persebaran pandemi Covid-19. Salaman sebagai tradisi masyarakat dalam berinteraksi terdampak oleh kebijakan tersebut dan menjadi kebiasaan yang harus ditinggalkan. Namun, masyarakat Debong Kidul meresponnya secara kreatif dan melakukan transformasi bersalaman menjadi saling tersenyum saat berjumpa dengan anggota masyarakat yang lain. Dengan demikian, makna esensial dari salaman sebagai representasi kehangatan hubungan personal tidak serta merta hilang meskipun perilaku tersebut tidak dapat mereka lakukan di saat pandemi. Saling melempar senyum dalam masa pandemi menjadi cara masyarakat Debong Kidul untuk terus memelihara tradisi interaksi yang penuh kehangatan dan personalitas. Pada akhirnya, pilihan masyarakat untuk mengubah perilaku bersalaman menjadi senyuman bukan hanya merupakan perilaku sosial dalam proses interaksi, akan tetapi juga telah menjelma menjadi perilaku kesehatan sebagai respon atas pandemi dan sekaligus respon atas kebijakan kesehatan yang diterapkan oleh pemerintah Kota Tegal.

\section{Ucapan Terimakasih}

Ucapan terimakasih kami sampaikan kepada Lembaga Penelitian dan Pengabdian Kepada Masyarakat (LPPM) Universitas Negeri Semarang yang telah mendukung terlaksananya penelitian ini melalui Skema Penelitian Terapan tahun 2020, dengan judul "Model Supercamp Candradimuka sebagai Arena Penguatan Prestasi dan Reputasi Internasional Mahasiswa FIS UNNES". Artikel ini merupakan produk 
dari salah satu aktivitas utamanya dalam skema tersebut yaitu melakukan project penelitian dan penulisan artikel bersama mahasiswa.

\section{Daftar Pustaka}

Aquarini, A. (2020). Pengaruh Kebijakan Politik terhadap Kepatuhan Physical Distancing Mencegah Penyebaran COVID-19. Anterior Jurnal, 19(2), 66-73.

Bungin, B. (2007). Metodologi Penelitian Kualitatif: Komunikasi, Ekonomi, Kebijakan Publik, dan Ilmu Sosial Lainnya (Edisi Kedua). Jakarta: Kencana Prenada Media.

Cahyo, S. D. (2017). Pembiasaan Jabat Tangan untuk Pembentukan Karakter Santun, Disiplin, dan Tanggung Jawab Penelitian Kualitatif di MI Ma-Arif Ngumpit Jenangan Kabupaten Ponorogo. Skripsi, Jurusan Pendidikan Guru Madrasah Ibtidaiyah. IAIN Ponorogo.

Caligiuri, P. (2020). Say Goodbye to Handshakes and Hugs. Entrepreneur and Innovation Exchange, April 2020.

CNN Indonesia. (2020). Jejak Kota Tegal Lawan Corona: Lantang Lockdown Hingga PSBB. Berita Peristiwa. Dikutip dari https://www.cnnindonesia.com/nasional/20200514134104-20-503332/jejak-kota-tegal-lawan-corona-lantang-lockdown-hingga-psbb

Erowati, D., Prasetyo, K. B., Astuty, S., dan Anggraeni, T. (2020). Peran Organisasi Perempuan dalam Penguatan Social Capital Melawan Pandemi Covid-19 (Studi pada Gerakan Kampanye Sosial Persit Kartika Chandra Kirana XXXIX Kabupaten Pati Jawa Tengah). Umbara: Indonesian Journal of Anthropology, 5(1), 30-41.

Fong, M. W., Gao, H., Wong, J. Y., Xiao, J., Shiu, E. Y. C., Ryu, S., dan Cowling, B. J. (2020). Nonpharmaceutical Measures for Pandemic Influenza in Nonhealthcare Settings-Social Distancing Measures. Emerging Infectious Diseases, 26(5), 976-984.

Galea, S., Merchant, R. M., dan Lurie, N. (2020). The Mental Health Consequences of COVID-19 and Physical Distancing: The Need for Prevention and Early Intervention. JAMA Intern Med, 180(6), 817-818.

Greenstone, M., dan Nigam, V. (2020). Does Social Distancing Matter? University of Chicago, Becker Friedman Institute for Economics Working Paper, (2020-26), 1-19.

Harahap, S. R. (2020). Proses Interaksi Sosial Di
Tengah Pandemi Virus Covid 19. AL-HIKMAH: Media Dakwah, Komunikasi, Sosial Dan Budaya, 11(1), 45-53.

Harnika, N. N. (2020). Strategi Komunikasi Melalui Media Visual Penyuluh Agama Hindu Pada Masa Pandemi Covid-19 di Kota Mataram. Jurnal SASAK: Desain Visual Dan Komunikasi, 2(2), 67-74.

Herdiana, D., dan Nurul, S. (2020). Implikasi Tatanan Normal Baru Terhadap Kehidupan Sosial Kemasyarakatan. Jurnal Ilmiah Dinamika Sosial, 4(2), 300-328.

Liputan6.com. (2020). Sebaran Kasus Covid-19 pada 7 Agustus, DKI dan Jawa Timur Tertinggi. Dikutip dari https://www.liputan6.com/ news/read/4325291/sebaran-kasus-covid-19pada-7-agustus-dki-dan-jawa-timur-tertinggi

Notoadmodjo. (2010). Metodologi Penelitian Kesehatan. Jakarta: Rineka Cipta.

Oxlund, B. (2020). An Anthropology of the Handshake. Anthropology Now, 12(1), 39-44.

Pesheva, E. (2020). Tackling Coronavirus. Dikutip dari Harvard Medical School website: https:// hms.harvard.edu/news/tackling-coronavirus

Pohan, R., Fitriati, L., dan Siregar, R. H. (2017). Program Mushafahah (Bersalaman) sebagai Upaya Character Building Pada Siswa Sekolah Dasar Islam Swasta Pekanbaru. Belajea: Jurnal Pendidikan Islam, 2(1), 1-20.

Rahmawati, E., dan Purwanto, A. D. (2019). Adaptasi Masyarakat terhadap Perubahan Penutup Lahan di Kecamatan Kelapa Kampit, Belitung Timur. Forum Ilmu Sosial, 46(2), 104-114.

Setiadi, T. (2020). Kawal Kebijakan Jokowi, Kota Tegal Terapkan New Normal Mulai 1 Juni. Dikutip dari Kompas. com website: https://regional.kompas.com/ $\mathrm{read} / 2020 / 05 / 29 / 21502701 /$ kawal-kebijakan-jokowi-kota-tegal-terapkan-new-normal-mulai-1-juni

Sekretariat Kabinet Republik Indonesia (2020). Kebijakan "Social" atau "Physical Distancing" Harus Libatkan Tokoh Sampai RT/ RW. Dikutip dari https://setkab.go.id/kebijakan-social-dan-physical-distancing-harus-libatkan-tokoh-sampai-rt-rw/

Soegiyono, P. D. (2017). Metode Penelitian Kualitatif, Kuantitatif dan R\&D. Bandung: Anggota Ikatan Penerbit Indonesia (IKAPI).

Soekanto, S. (2017). Sosiologi Suatu Pengantar. Jakarta: Rajawali Pers.

Triwibowo, C. (2015). Pengantar Dasar Ilmu Kesehatan Masyarakat. Yogyakarta: Nuha 
Medik.

Wang, Z., Qiang, W., Ke, H. (2020). A Handbook of 2019-nCoV Pneumonia Control and Prevention. China: Hubei Science and Technology Press.

Wardiah, M. L. (2016). Teori Perilaku dan Budaya Organisasi. Bandung: Pustaka Setia.

World Health Organization. (2020). Covid-19: Physical Distancing. Dikutip dari https:// www.who.int/westernpacific/emergencies/covid-19/information/physical-distancing\#: :text=Physical distancing helps limit the,Break the chain of transmission 